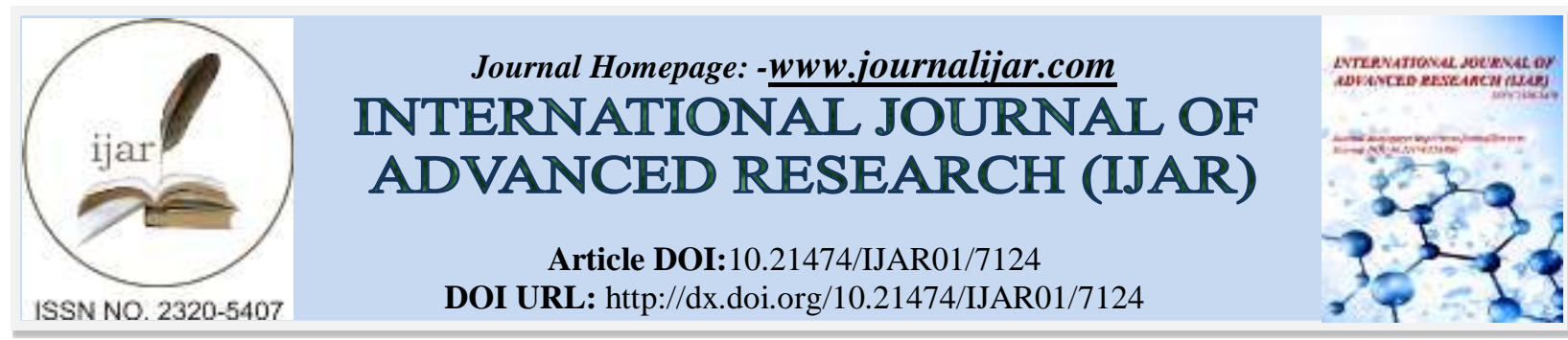

RESEARCH ARTICLE

\title{
MORPHOMETRIC AND HISTOLOGICAL STUDIES OF EFFECTS OF AQUEOUS EXTRACT OF COSTUS AFER STEM JUICE ON CUTANEOUS WOUND OF ALBINO RATS.
}

\author{
Akpan Udo Ekanem ${ }^{1}$, Kudighe Patrick Udoh ${ }^{2}$ and Aniekan Imo Peter'. \\ 1. Department of Anatomy, University of Uyo, Nigeria. \\ 2. Community Health Officers Training School, University of Uyo Teaching Hospital, Nigeria.
}

\section{Manuscript Info}

Manuscript History

Received: 18 March 2018

Final Accepted: 20 April 2018

Published: May 2018

Keywords:-

wound healing, Costus afer stem, regeneration of skin, dermal organization, tensile strength.

\begin{abstract}
The aim of this study was to investigate the morphometric and histological effects of aqueous extact of Costus afer stem on rat skin wound. Phytochemical analysis of the extract showed the presence of saponin, alkaloids, lignans, terpenes, quinones, stilbenes and flavonoids. Calcium, magnesium, potassium, copper, manganese and phosphorus were also detected in the extract. Twenty-five adult female albino rats with weights between 243-320g were used for the study. The rats were divided equally into 5 groups. They were wounded on their dorsum under ketamine hydrochloride anaesthesia. Immediately hemostasis was attained, the rats were treated according to their groups. Group A wounds were left without treatment, group B were treated only on the first day with iodine ointment, group $\mathrm{C}$ were treated for 7days with iodine ointment, group D were treated only on the first day with Costus afer paste, and group E were treated for 7days with Costus afer paste. Using ruler android application, the rate of contraction was not significantly different across the groups and the rate of reepithelialization was significantly highest in group $\mathrm{D}$ at $\mathrm{p}<0.05$. the tensile strength measured with tensiometer was significantly highest $(\mathrm{p}<0.05)$ in group D at $692.20 \mathrm{~g}$. Masson's trichrome sections showed randomly organized collagen fibres in group D and E. There was also indication of growing hair follicles in group D. In conclusion, aqueous extract of Costus afer stem prove to be more effective in wound healing than iodine and its stem juice can be used cautiously for wound treatment.
\end{abstract}

Copy Right, IJAR, 2018,. All rights reserved.

\section{Introduction:-}

Wound is a disruption of cellular, anatomical, and functional continuity of a living tissue. It results from injuries to the skin that may disrupt underlying soft tissues (Thakur et al., 2011). Immediately after wounding, the body responds through a complex cascade of cellular and biochemical interactions leading to the restoration of structural and functional integrity of the injured tissue. The healing process begins at the moment of injury and involves both resident and migratory cell populations, extracellular matrix and the actions of soluble mediators. This process is directed towards the restoration of the damaged tissue either by fibrosis or regeneration and proceeds through three overlapping phases of inflammation, proliferation and tissue remodelling (Mendonca and Coutinho-Netto, 2009; Velnar et al., 2009). 
Many measures have been employed clinically and traditionally to enhance the healing process. Traditionally, most of these measures involve various plant products and many of such plants have been scientifically proven to be effective in wound healing (Thakur et al., 2011; Budovsky et al., 2015; Saini et al., 2016).

Costus afer, commonly called ginger lily, is a relatively tall perennial unbranched, semi-woody herb found mainly in the wild throughout the forest regions of tropical Africa (Omokhua, 2011; Hyde et al., 2017). The plant parts have been used in the treatment of rheumatic swellings, cuts or sores and other ailments (Odugbemi, 2008). The semiwoody stem of Costus afer has been employed traditionally for the treatment of wounds. The sap is said to be burning on open wounds with anodyne and healing properties (Burkill, 1985; Fern, 2014). This correlates with scientific investigations showing that the stem of Costus afer has significant antimicrobial, anti-inflammatory and antinociceptive properties which are necessary for effective wound healing (Anyasor et al., 2010; Akaninwor et al., 2014; Fern, 2014; Ijioma et al., 2014; Uchegbu et al., 2016). According to Agyare and colleagues (2016), the presence of any two of these properties in a plant suggests its wound enhancement potential.

In addition, the phytochemistry of the stem of Costus afer has been found to be rich in pro-healing biomolecules and minerals such as alkaloids, saponins, flavonoids, quinones, potassium, sodium, calcium and magnesium (Akpabio $e t$ al; 2012; Anyasor et al; 2014). The safety of the stem has been confirmed with acute toxicity higher than $5000 \mathrm{mg} / \mathrm{kg}$ b.w. of mice and chronic consumption has been reported to show no significant adverse effect on the biochemistry and histology of major organs and tissues of the body (Goodies et al., 2015; Tonkiri et al., 2015; Akpantah et al., 2016). This study was therefore carried out to investigate the morphometric and histological effects of aqueous extract of Costus afer stem juice on the cutaneous wounds of adult albino rats.

\section{Methodology:-}

This study was done in the experimental laboratory of the department of Anatomy, University of Uyo, Nigeria. The ethical approval for the study was duly obtained from the ethical committee of Faculty of Basic Medical Sciences, University of Uyo, Nigeria. Three days before commencement of the study, all apparatus to be used for the study including the room were decontaminated by soaking overnight in concentrated antiseptic solution and left for 48hours to allow complete dissipation of the antiseptic before bringing in the rats. The beddings, napkins, gauze and all dissecting instruments to be used were sterilized by autoclaving at $138^{\circ} \mathrm{C}$.

\section{Research animals:-}

Twenty-five (25) adult female albino rats weighing between 243-320g were used for the study. The rats were housed individually in plastic cages under temperature between $22-26^{\circ} \mathrm{C}$, humidity range of $50-60 \%$, and 12 hours light/dark lighting. They were fed with standard rat pelletized diet (Vital Feed Growers, Green Cereals Nigeria Ltd.) and water ad libitum.

\section{Plant Collection and Preparation of Extract:-}

Identification and registration of Costus afer were done by staff of the Herbarium of the Department of Pharmacognosy, Faculty of Pharmacy, University of Uyo and assigned herbarium number UUPH26(a). The plant was collected fresh from bushes within Uyo Local government area, Nigeria in February, 2017. After removal of the foliage leaves, the stems were washed, cut into pieces and crushed in an electric blender (NAKAI-Japan; HR-2818). The juice obtained from the blending was filtered with a chess cloth. Aqueous crude extract of the filtrate was obtained by evaporation in beakers placed in water-bath at $40^{\circ} \mathrm{C}$ (Akpantah et al., 2016).

\section{Phytochemical Analysis:-}

Quantitative phytochemistry of the extract was done to check its chemical and mineral constituents. The analysis was carried out for phenols, stilbenes, flavonoids, quinones, triterpenes, saponins, cyanides, sodium, calcium, magnesium, copper, manganese, phosphorus and potassium. The analysis of saponin, alkaloid, trterpene, tannin, flavonoid, phenol and cyanide was according to the procedure explained by Ekwueme and colleagues (2015). Calcium, magnesium, copper, manganese, and phosphorus were determined according to the method of Vogel (1989) using Atomic Absorption Spectroscopy (AAS), while sodium and potassium were determined by flame photometer method.

\section{Experimental Protocol:-}

The albino rats were divided equally into 5 groups of A, B, C, D and E for each treatment procedure. After one week of acclimatization, all the rats were wounded on their dorsum and treated according to group specifications. The 
health status of the rats was monitored closely by regular assessment of their weight and stress indicators according to National Centre for the Replacement, Refinement and Reduction of Animals in Research (Sotocina et al., 2011), as well as internationally accepted standard guide for care and use of laboratory animals promulgated and adopted by the National Institute of Health $(\mathrm{NIH})$ publication number 85(23), revised 1996 and related ethics and regulation. Throughout the experiment, all procedures were carried out with high degree of asepsis and no infection was observed in the wounds.

\section{Wound Creation:-}

All wound creations were carried out under controlled aseptic environment. The rats were under general anaesthesia with ketamine hydrochloride $(120 \mathrm{mg} / \mathrm{kg}$ b.w. i.p.) throughout the procedure. The rats were shaved on their dorsum using clipper (model number GM-3005). The shaved area was cleaned with an antiseptic agent and methylated spirit. Within the shaved area, $1.5 \times 1.5 \mathrm{~cm}^{2}$ was marked off as the wounding site using methylene blue and the rat was draped for surgery. The target area was excised with surgical blade, scissors and forceps to create a full thickness square wound. Immediately after wounding, sterile gauze was used to apply pressure on the wound until haemostasis was attained.

\section{Application of Substances:-}

The plant extract was made into a semiliquid paste of $4 \mathrm{~g} / \mathrm{ml}$ concentration. Povidone iodine ointment (Wosan Iodine, Jawa International Nigeria Limited) with $5 \% \mathrm{w} / \mathrm{w}$ concentration was also used for the study. Wounds of group A rats were left untreated; group B were treated only on the first day with $0.2 \mathrm{ml}$ of iodine ointment; group C were treated for 7 days with $0.2 \mathrm{ml}$ of iodine ointment, once daily or 7 days; group D were treated only on the first day with $0.2 \mathrm{ml}$ of Costus afer paste, while group E were treated with $0.2 \mathrm{ml}$ of Costus afer paste once daily for 7days.

\section{Morphometric Assessment:-}

Rate of Contraction: The rate of contraction of healed tissue was assessed by measuring the size of the open wound every 2 days. The wounds were measured digitally to prevent infection. Photographs of the wounds were taken with a Debit Card placed beside the rats and on the same plane. An android application called Ruler (version 1.04.191) was used to analyse the size of the wound with the short side of the Debit Card serving as standard.

Rate of Re-Epithelialization: This was evaluated by dividing the original size of the wound by the time taken for the wound to completely heal.

Tensile Strength Measurement: The wounds were considered to be completely healed when the wound site was fully covered with epidermis without any visible blood vessels. On the day complete healing was observed for each rat, such animal was taken out and euthanized by chloroform inhalation. Immediately after euthanasia, the tensile strength of the healed tissue was evaluated using a tensiometer constructed according to the design of Kokane and colleagues (2009).

\section{Histological Study:-}

After tensile strength evaluation, the rat was sacrificed and samples of the wound site were collected. The samples were fixed immediately in $10 \%$ buffered formalin and processed for Mason's Trichrome staining method for collagen (Masson, 1929).

\section{Data Analysis:-}

Data collected from the different groups of animals were expressed in mean \pm SD and analysed with SPSS (version 20), using ANOVA with Tukey's and Dunnett's post hoc tests at $\mathrm{p}<0.05$ significance.

\section{Results:-}

Phytoconstituents of Costus afer:-

Results of the phytochemical analysis showed that the stem juice of Costus afer contain the following phytochemicals and minerals in tables 1 and 2 . 
Table 1:-Phytoconstituents of aqueous extract of Costus afer stem juice

\begin{tabular}{|l|l|}
\hline Test & Percentage (mean \pm S.D.) \\
\hline Saponins & $2.01 \pm 0.04$ \\
\hline Alkaloids & $14.02 \pm 0.09$ \\
\hline Tannins & - \\
\hline Flavonoids & $1.12 \pm 0.03$ \\
\hline Phenol & - \\
\hline Terpene (triterpene) & $0.11 \pm 0.04$ \\
\hline Quinones & $0.09 \pm 0.08$ \\
\hline Lignans & $4.03 \pm 0.05$ \\
\hline Stilbenes & $0.36 \pm 0.1$ \\
\hline
\end{tabular}

Table 2:-Mineral compositions in aqueous extract of Costus afer stem juice

\begin{tabular}{|l|c|}
\hline Mineral & $\begin{array}{l}\text { Composition } \\
(\mathbf{m g} / \mathbf{1 0 0 g})\end{array}$ \\
\hline Sodium & $0.39 \pm 0.12$ \\
\hline Calcium & $16.38 \pm 0.04$ \\
\hline Magnesium & $15.40 \pm 0.09$ \\
\hline Copper & $0.02 \pm 0.08$ \\
\hline Manganese & $0.01 \pm 0.04$ \\
\hline Phosphorus & $7.59 \pm 0.02$ \\
\hline Potassium & $18.72 \pm 0.06$ \\
\hline
\end{tabular}

Composition given in mean \pm SD

\section{Morphometric assessment:-}

\section{Rate of Contraction:-}

The rate of contraction was highest in the control or group A and lowest in group D, treated only on the first day with Costus afer. However, there was no significant difference between the rates of wound contraction across the groups (Figure 2).

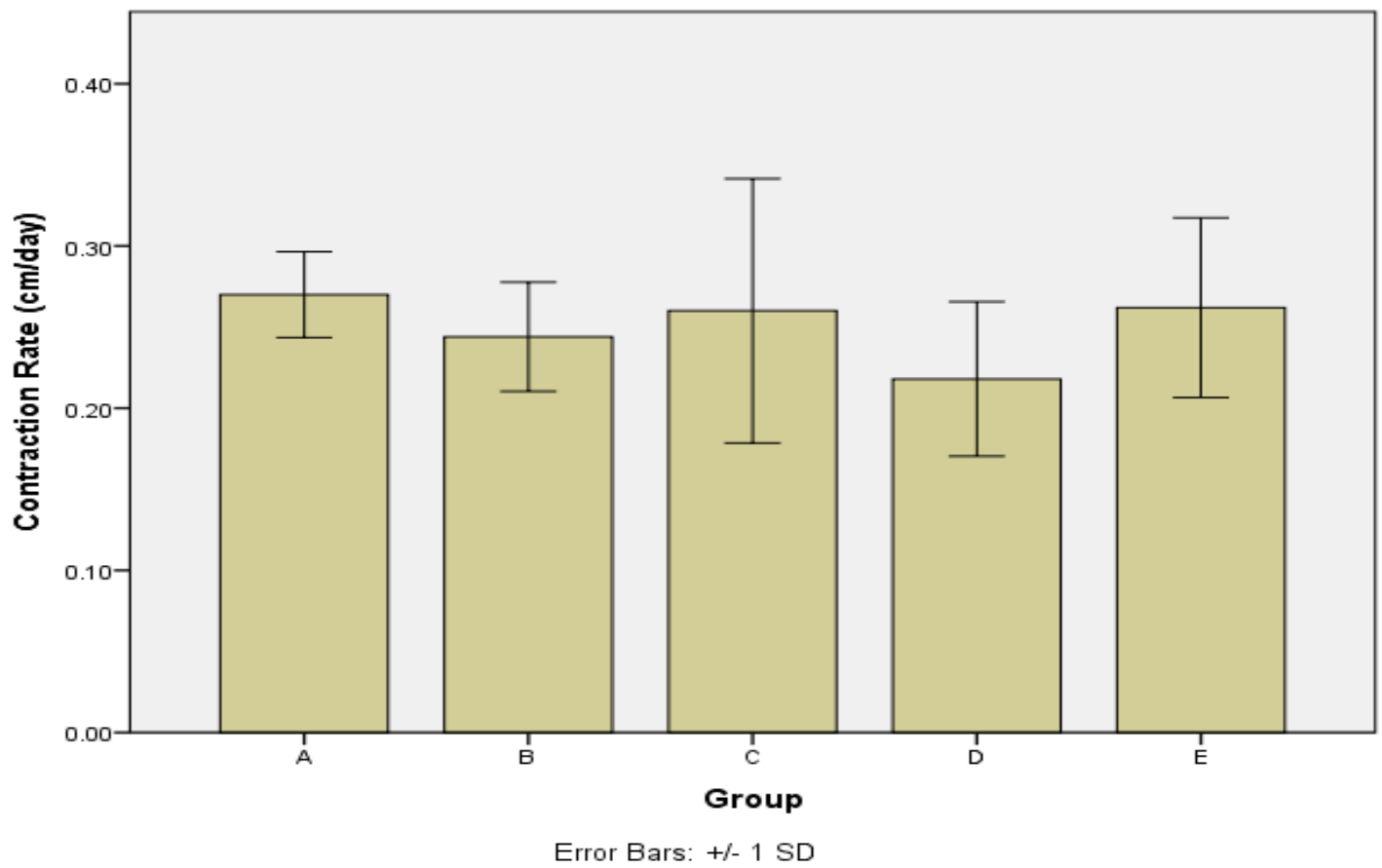

Figure 1:-Rate of wound contraction from each experimental group. There was no significant difference across the groups $(\mathrm{p}=0.558)$. 


\section{Rate of re-epithelialization:-}

This was found to be significant and fastest in group D, treated only on the first day with Costus afer but slowest in the control or group A (Figure 3).

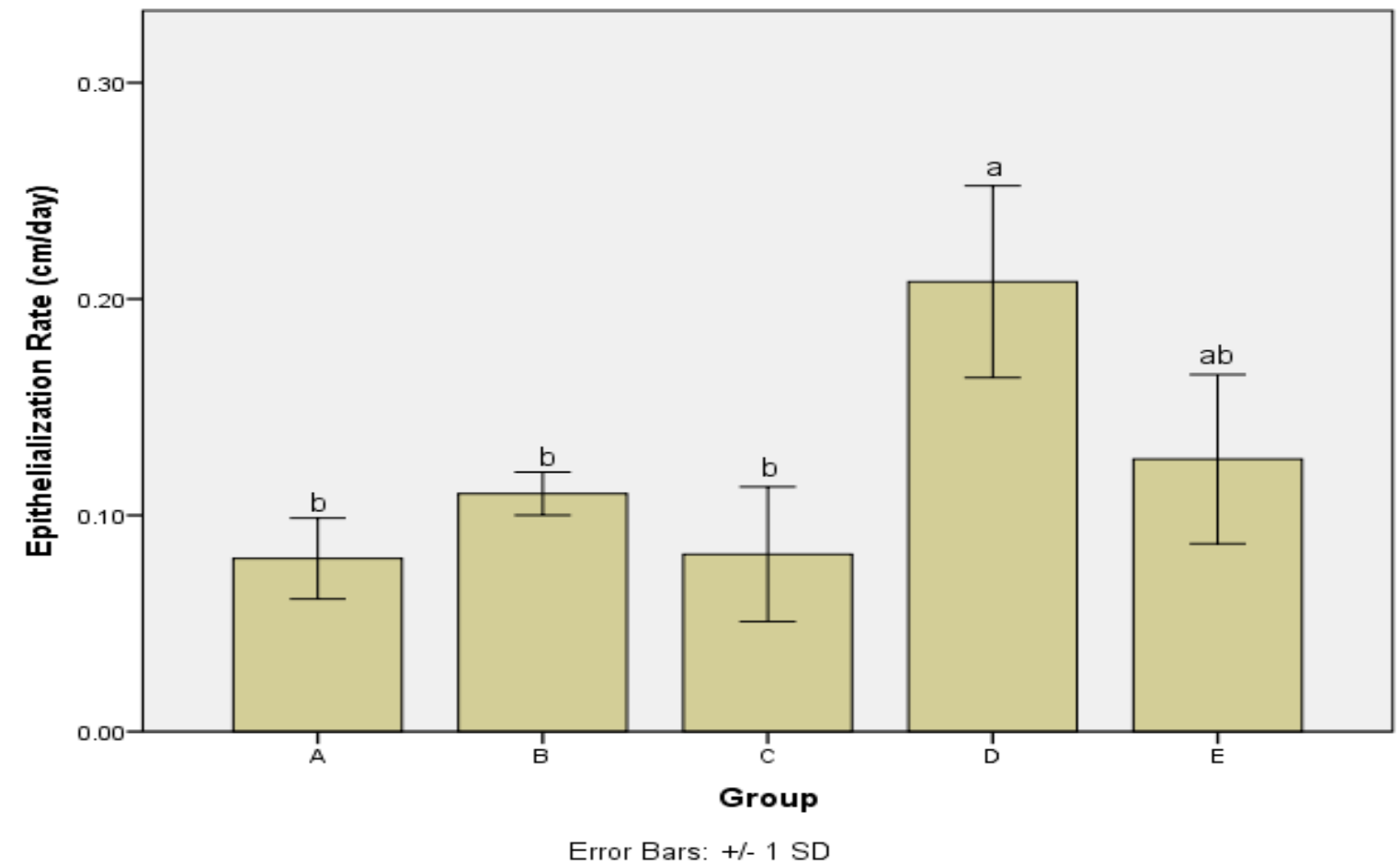

Figure 2:-Rate of re-epithelialization of the wound surface from each experimental group. a,b: bars with different annotations are significantly different $(\mathrm{p}=0.00)$.

\section{Tensile strength of tissue:-}

The tensile strength of group D, treated only on the first day with aqueous extract of Costus afer stem, was the highest and increased significantly while that of group C, treated for 7 days with iodine ointment, was the least and reduced significantly, when compared with that of group A (Table 4).

Table 1:-Tensile strength of healed tissue

\begin{tabular}{|l|l|l|}
\hline Groups & No. & Tensile Strength $(\mathbf{g})$ \\
\hline A & 5 & $526.00 \pm 52.52^{\mathrm{c}}$ \\
\hline B & 5 & $516.20 \pm 72.87^{\mathrm{c}}$ \\
\hline C & 5 & $308.00 \pm 34.59^{\mathrm{b}}$ \\
\hline D & 5 & $692.20 \pm 12.32^{\mathrm{a}}$ \\
\hline E & 5 & $564.20 \pm 29.32^{\mathrm{c}}$ \\
\hline p-value & & $\mathbf{0 . 0 0 0}$ \\
\hline
\end{tabular}

\section{Histological Analysis:-}

Photomicrographs of Masson's Trichrome stained sections of the healed dermis of groups D and E showed irregular organization of collagen fibres similar to normal dermis (Figures 4, 8, and 9). Growing hair follicles were also observed for group D, treated only on the first day with Costus afer extract (Figure 8). In groups A, B, and C, the dermal fibres were oriented parallel to the plane of the skin with few crosslinks giving a basket appearance (Figures 5,6 and 7). 


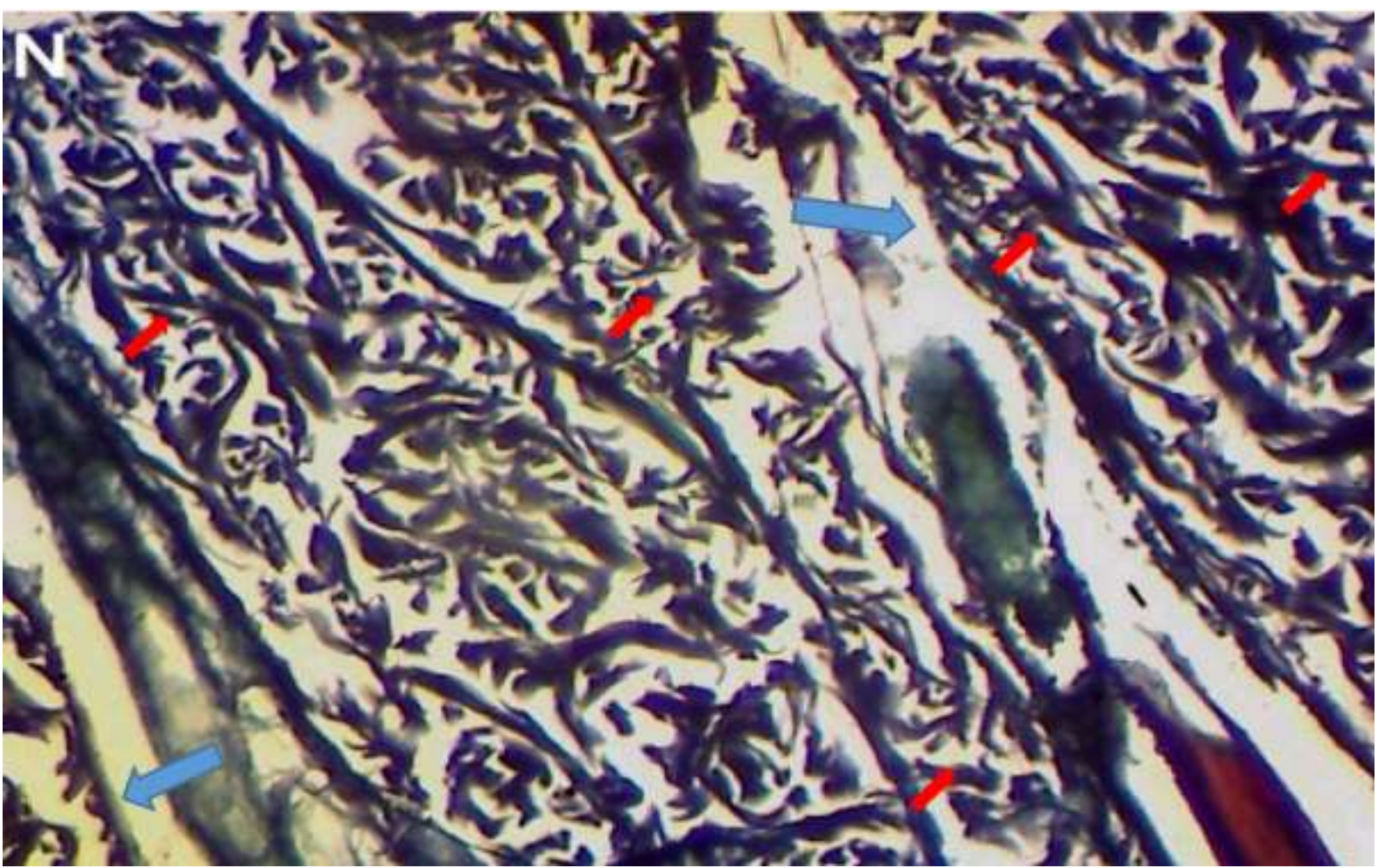

Figure 3:-Normal dermal tissue with random organization of collagen fibres (red arrows) from normal uninjured skin. Hair fibres are clearly visible (blue arrows) (Masson's trichrome, x100)

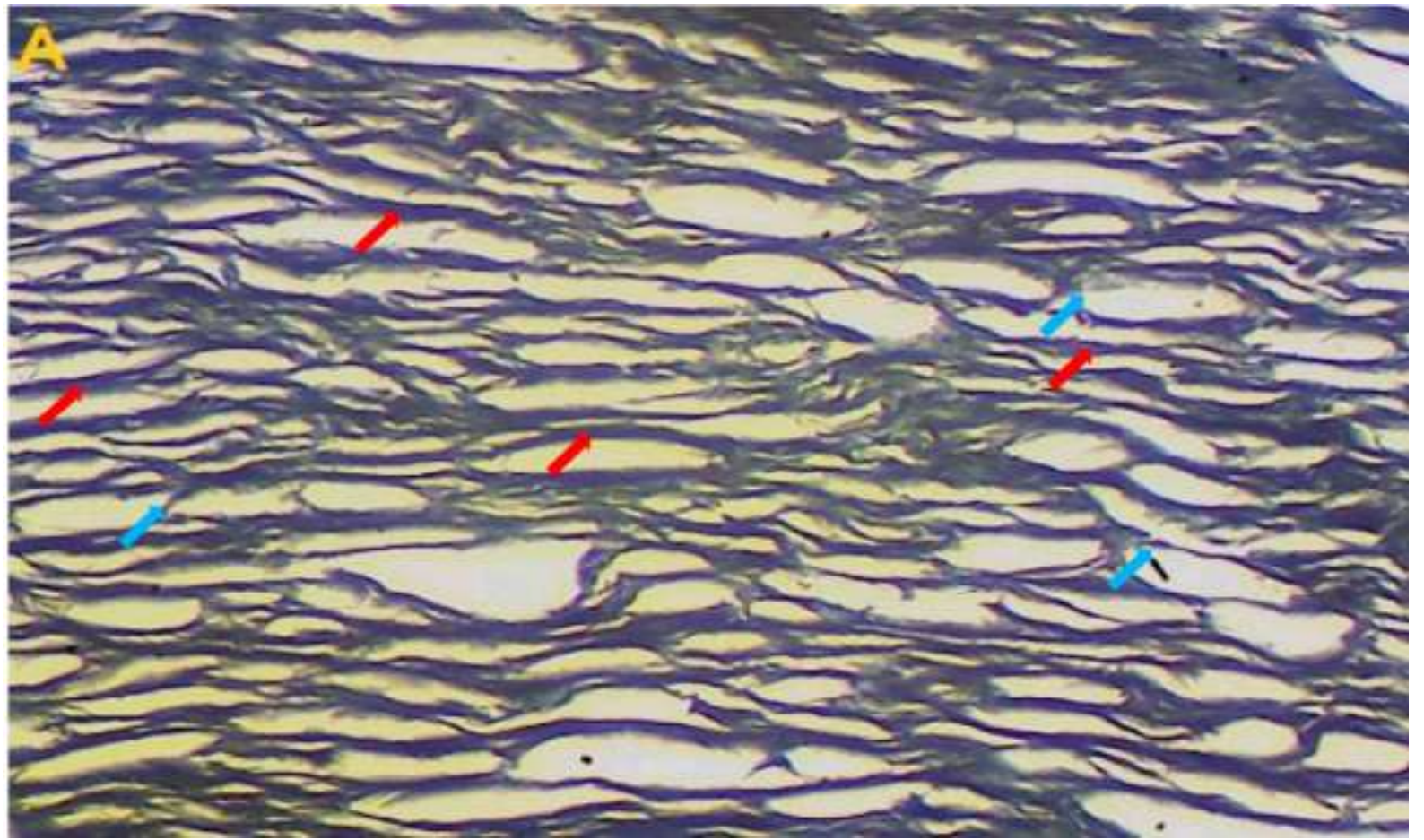

Figure 4:-Healed dermal tissue with planar orientation of collagen bundles (red arrows) from control, group A. The bundles are thin, parallel fibres with cross links (blue arrows) giving a basket weave appearance (Masson's trichrome, $\mathrm{x} 100$ ) 


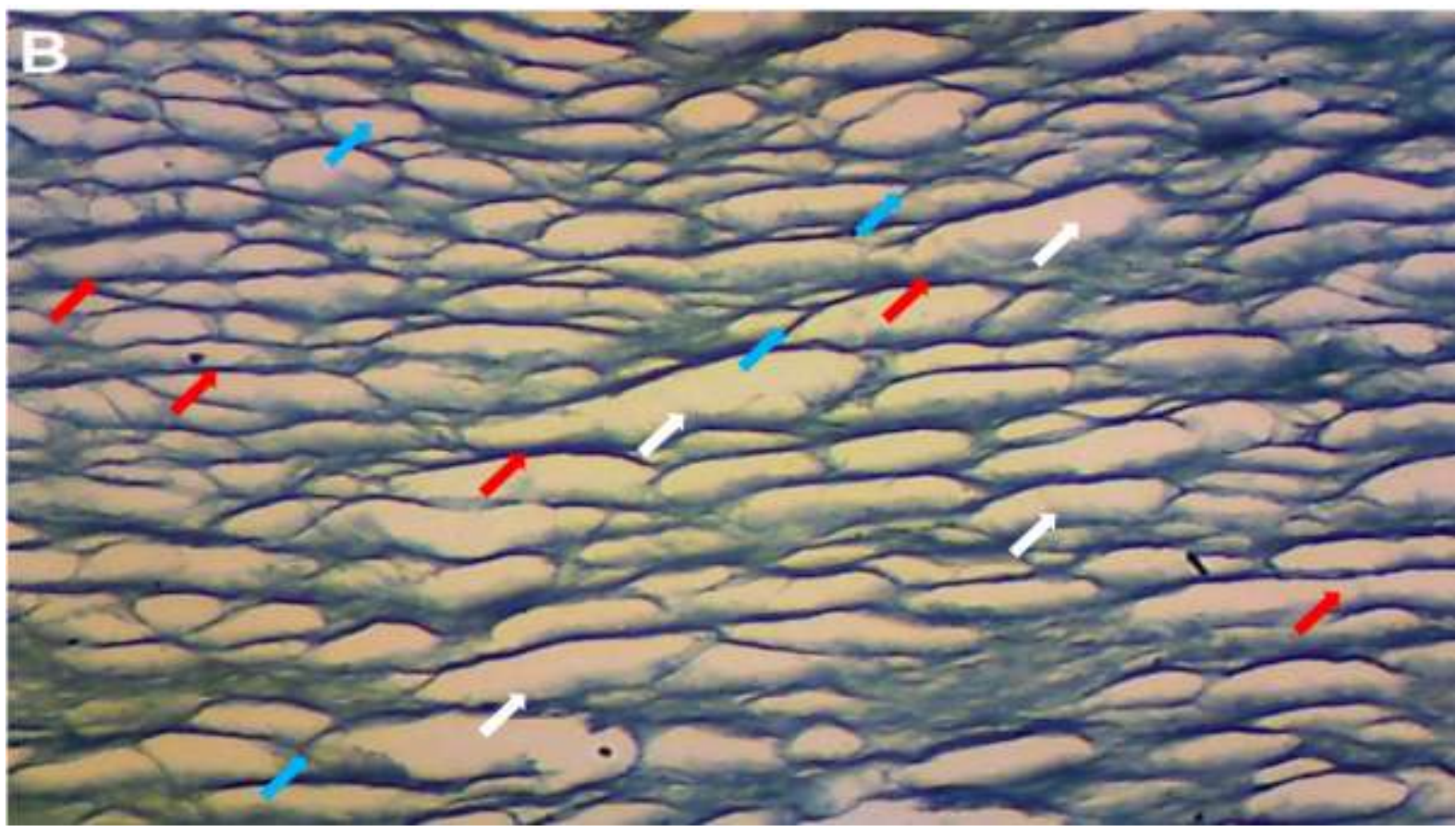

Figure 5:-Healed dermal tissue with basket weave appearance of collagen bundles from group B, treated only on the first day with iodine ointment. The bundles are thin (red arrows) and have crosslinks (blue arrows) that loosely interlace with prominent interstices (white arrows) (Masson's trichrome x100)

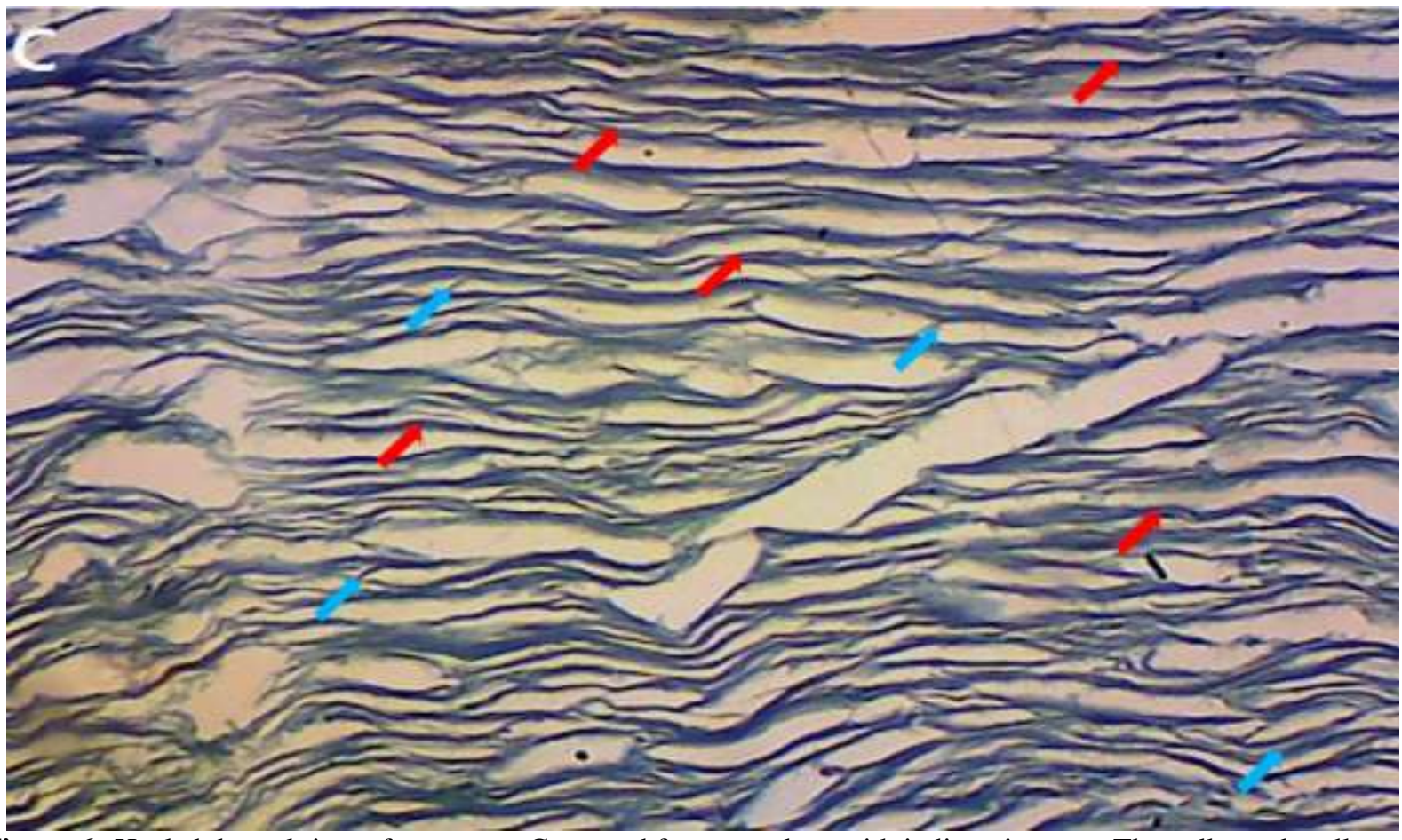

Figure 6:-Healed dermal tissue from group C, treated for seven days with iodine ointment. The collagen bundles are thin and run closely in parallel (red arrows). There are fewer crosslinks (blue arrows) (Masson's trichrome x100) 


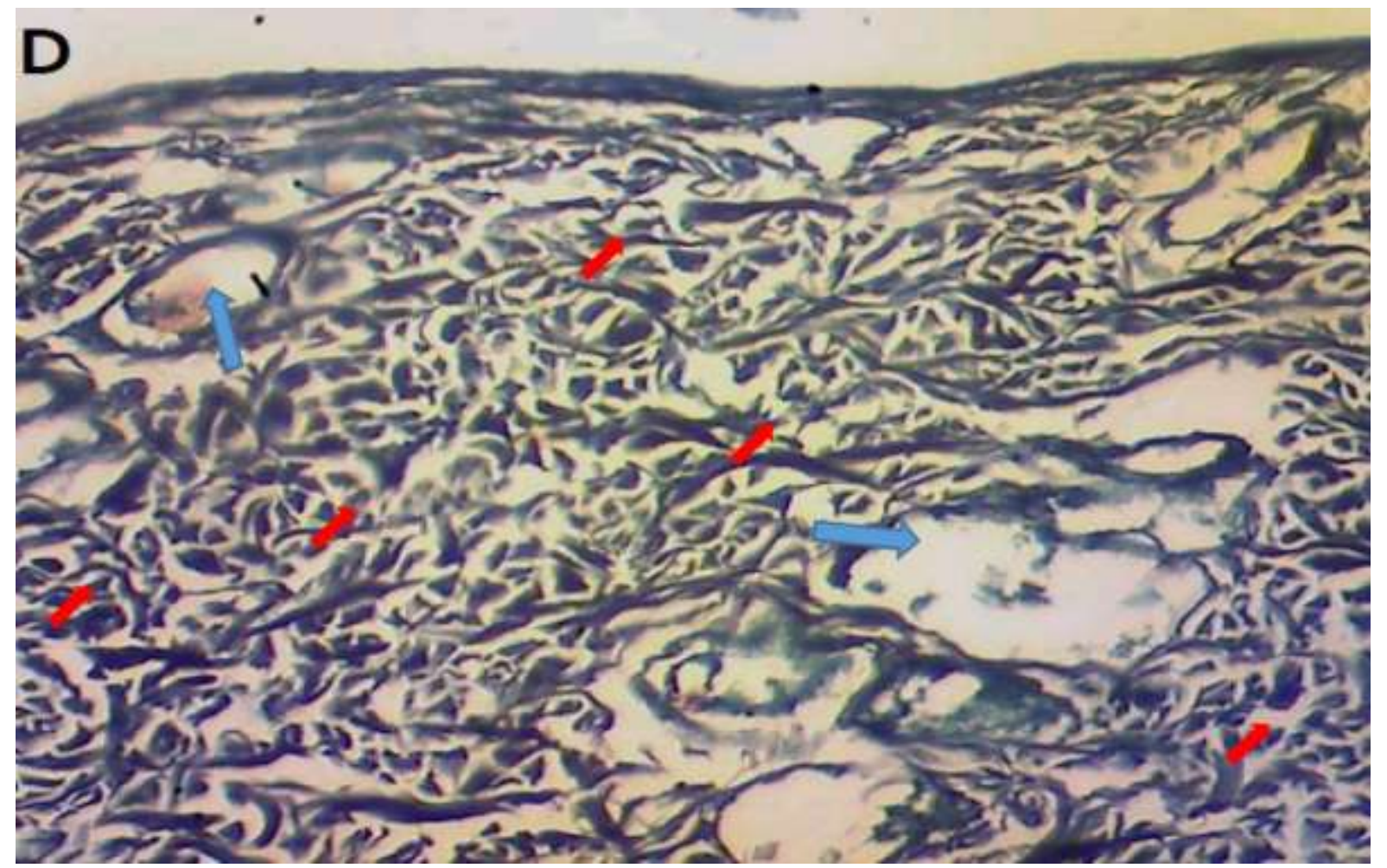

Figure 7:-Healed dermal tissue from group D, treated only on the first day with Costus afer extract. Collagen bundles are tightly and randomly organized (red arrows). There are also developing hair follicles (blue arrows) (Masson's trichrome x100)

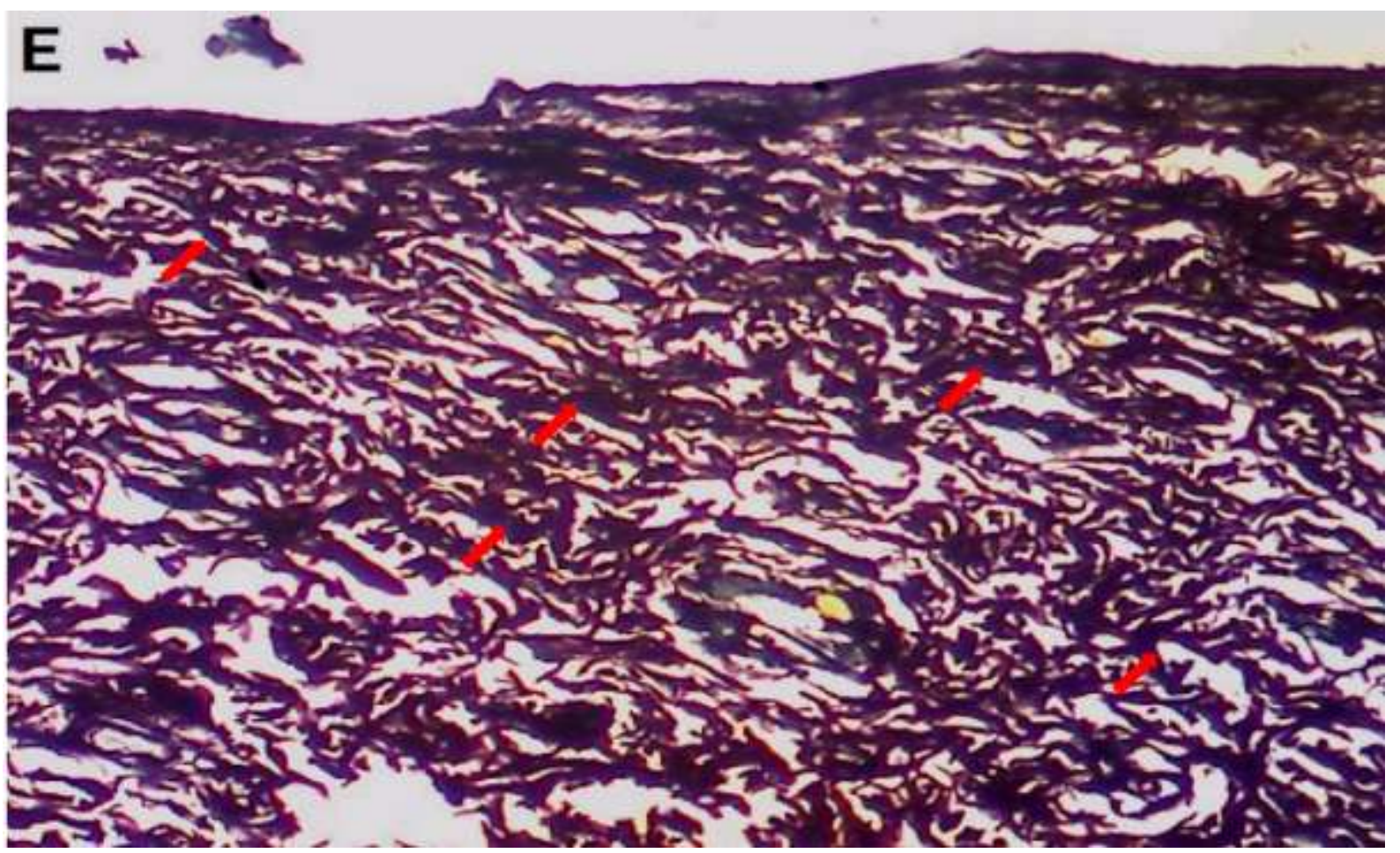

Figure 8:-Healed dermal tissue from group E, treated for seven days with Costus afer extract. Fibres are randomly organized (arrows) (Masson's trichrome, x100) 


\section{Discussion:-}

The wound healing biomolecules and minerals present in the extract indicated its propensity to enhance wound healing. This was observed from the outcome of the healing process during the study. Alkaloids, being the most abundant biomolecule in the extract might have contributed significantly to the healing process. This class of biomolecules have been reported to be bactericidal, anti-inflammatory and antioxidants which are essential for effective wound healing (Devkota and Tshikalange, 2013; Cushnie et al., 2014). The alkaloids might also be responsible for the faster rate of re-epithelialization as it has been reported to stimulate cell proliferation and migration. Their ability to enhance collagen deposition and organisation during wound healing might have contributed to the near-normal collagen organisation and high tensile strength observed in groups treated with aqueous extract of Costus afer paste (Nesterova et al., 2012; Tsala et al., 2013; Mahibalan et al., 2016).

These healing effects may also be augmented by other biochemical components of Costus afer that share similar properties of alkaloids. For instance, flavonoids, lignans, stilbenes, quinones and triterpenes are also known to be anti-inflammatory, antioxidant and anti-microbial. Wounds treated with quinones have been reported to exhibit high rate of epithelialization which may be applicable in this study. In addition, quinones and triterpenes have been reported to promote high deposition and crosslinking of collagen fibres by enhancing fibroblast migration and activities during wound healing as observed in this study (Ngameni et al., 2013; Tsala et al., 2013). The antagonistic effect of flavonoids in stimulating the expression of matrix metalloproteinase-1 (MMP-1) may ensure that collagen deposition and crosslinking is not beyond the level found in uninjured tissues (Cho et al., 2010; Tsala et al., 2013). The coordinated activities of these biomolecules made significant contribution to the random and close organization of the collagen fibres which conferred a high tensile strength to the healed tissue of wounds treated with aqueous extract of Costus afer stem juice.

The presence of calcium, magnesium, copper, potassium, phosphorus and manganese in the extract act in part to regulate the activities of enzymes and growth factors in the wound environment. Magnesium and calcium are involved in many biological processes in the body including protein and DNA synthesis and signal transduction. Studies have shown that high concentration of magnesium as observed in the extract, enhances wound healing. Magnesium, being a cofactor of over 300 enzyme systems in the body, its direct presence at the wound site may speed up the activity of several enzymes especially those functioning in the ECM. According to Wang (2013), regulation of potassium channels enhances wound healing process. Therefore, magnesium may also contribute to the healing process by its involvement in active transport of calcium and potassium ions across cell membranes as well as energy production (Rude, 2012; NIH, 2016). The additional phosphorus from the extract may help increase its availability to enhance DNA and RNA synthesis, activation and deactivation of enzymes, and regulation of the use of other minerals at the wound site.

Copper is another essential mineral that plays significant role in wound healing, including regulation of expression and activities of growth factors and cytokines (Borkow, 2004; Kornblatt et al., 2016). Thus, it may contribute to the regenerative effect of the Costus afer stem juice. Moreover, it has been reported that copper can upregulate the expression of hypoxia inducible factor-1 (HIF-1) which is a regenerative component of most regenerating tissues including foetal skin (Cai et al., 2013; Hong et al., 2014; Kitch, 2014). Copper may also contribute to the increased rate of re-epithelialization by promoting angiogenesis as well as the formation of fibronectin mats as scaffolds for the proliferating and migrating cells (Sen et al., 2002; Borkow, 2004; Kitch, 2014). According to Kitch (2014), copper is involved in the synthesis and organization of collagen and elastin fibres, and this role may contribute to the formation of a near-normal dermis as found in the wound treated only on the first day with Costus afer paste. This effect is likely to be fuelled by the presence of manganese in the extract, which activates the enzyme prolidase to provide proline for collagen and elastin synthesis (Kitchener and Grunden, 2012). In addition, manganese may also contribute to cell migration by enhancing the synthesis of glycosaminoglycans in the ECM (Higdon and Drake, 2010).

The rate of wound contraction and tissue regeneration are inversely related (Yannas, 2008). The integrated activities of the biomolecules and minerals in the plant extract may have borne insignificant effect on the rate of contraction, thereby driving the healing process towards regeneration of loss tissue. This is evidenced in the high rate of reepithelialization, near-normal dermal organization, high tensile strength, and indication of hair follicles observed in healed tissues from treatment with aqueous extract of Costus afer paste. 


\section{Conclusions:-}

The morphometric and histological assessment of the healing effects of aqueous extract of Costus afer paste has indicated its potential in the regeneration of injured tissue. This has been shown in its ability to produce a healed tissue with dermal organization similar to normal uninjured tissue and the development of hair follicles. Therefore, it is recommended that with more refinement to the aqueous extract of Costus afer stem juice, it could be applied to enhance the healing process of cutaneous wounds.

\section{Sources of funding:-}

This study was funded by the researchers

\section{Conflict of Interest:-}

The authors declare that no conflict of interest is associated with this study.

\section{Author Contributions:-}

All authors contributed sufficiently to the intellectual concept, design of the study and development of the manuscript.

\section{References:-}

1. Agyare, C., Bekoe, E. O., Boakye, Y. D., Dapaah, S. O., Appiah, T., \& Bekoe, S. O. (2016). Medicinal Plants and Natural Products with Demonstrated Wound Healing Properties. In Wound Healing - New insights into Ancient Challenges. pp. InTech. 484-513. http://doi.org/10.5772/63574

2. Akaninwor, J. O., Essien, E. B., Tonkiri, A., \& Uvoh, S. M. (2014). Phytoconstituents of Costus afer Methanolic Stem Extract and Its in vitro Radical Scavenging Activities. Journal of Agriculture and Biodiversity Research, 3(7): 99-110.

3. Akpabio, U. D., Udo, U. E., \& Akpakpan, A. E. (2012). Evaluation of phytochemical, proximate and mineral element composition of stem of Costus afer (Bush cane). Asian Journal ofPlant Science and Research, 2(5): 607-612.

4. Akpantah, A. O., Akpan, U., Eluwa, M. A., Isamoh, T. E., Udonkang, M., \& Ekanem, T. B. (2016). Blood Parameters and Spleen Histology Following Chronic Consumption of Ethanolic Extract of Costus afer Stem and Juice on Albino Wistar Rats. British Journal of Medicine \& Medical Research, 13(12): 1-10. http://doi.org/10.9734/BJMMR/2016/23414

5. Anyasor, G. N., Ogunwenmo, K. O., Oyelana, O. A., \& Akpofunure, B. E. (2010). Phytochemical constituents and antioxidant activities of aqueous and methanol stem extracts of Costus afer Ker Gawl. (Costaceae). African Journal of Biotechnology, 9(31), 4880-4884.

6. Anyasor, G. N., Onajobi, F. D., Osilesi, O., \& Adebawo, O. (2014). Proximate composition, mineral content and in vitro antioxidant activity of leaf and stem of Costus afer (Ginger lily). Journal of Intercultural Ethnopharmacology, 3(3): 128-34. http://doi.org/10.5455/jice.20140527085848

7. Borkow, G. (2004). Copper's role in wound healing. Property of Cupron Inc, 1-12.

8. Budovsky, A., Yarmolinsky, L., \& Ben-Shabat, S. (2015). Effect of medicinal plants on wound healing. Wound Repair and Regeneration, 23(2): 171-183. http://doi.org/10.1111/wrr.12274

9. Burkill, H. M. (1985). Costus afer Ker-Gawl. [family Costacae]. Retrieved January 6, 2017, from http://plants.jstor.org/stable/10.5555/al.ap.upwta.1_1139

10. Cai, Z., Li, H., Zhang, H., Han, S., An, R., \& Yan, X. (2013). Novel insights into the role of hypoxia-inducible factor-1 in the pathogenesis of human post-intubation tracheal stenosis. Molecular Medicine Reports, 8(3): 903-908. http://doi.org/10.3892/mmr.2013.1595

11. Cho, J. W., Cho, S. Y., \& Lee, K. S. (2010). Onion extract and quercetin induce Matrix metalloproteinase-1 in vitro and in-vivo. International Journal of Molecular Medicine, 25(3): 347-352.

12. Cushnie, T. P. T., Cushnie, B., \& Lamb, A. J. (2014). Alkaloids: an overview of their antibacterial, antibioticenhancing and antivirulence activities. International Journal of Antimicrobial Agents, 44(5): 377-86. http://doi.org/10.1016/j.ijantimicag.2014.06.001

13. Ekwueme, F. N., Nwodo, O. F. C., Joshua, P. E., Nkwocha, C., \& Eluka, P. E. (2015). Qualitative and Quantitative Phytochemical Screening of the Aqueous Leaf Extract of Senna mimosoides : Its Effect in in vivo Leukocyte mobilization induced by inflammatory stimulus. International Journal of Current Microbiology and Applied Sciences, 4(5): 1176-1188.

14. Fern, K. (2014). Costus afer - useful tropical plant. Retrieved June 1, 2017, from 
http://tropical.theferns.info/viewtropical.php?id=Costus+afer

15. Goodies, M. E., Emmanuel, I. E., \& Earnest, E. O. (2015). Evaluation of the Ulcerogenic potential of the Aqueous extract of Spondias mombin and Costus afer. International Journal of Advances in Pharmacy, Biology and Chemistry, 4(2): 282-286.

16. Higdon, J., \& Drake, V. J. (2010). Manganese. Retrieved June 2, 2017, from http://lpi.oregonstate.edu/mic/minerals/manganese

17. Hong, W. X., Hu, M. S., Esquivel, M., Liang, G. Y., Rennert, R. C., McArdle, A., ... Longaker, M. T. (2014). The Role of Hypoxia-Inducible Factor in Wound Healing. Advances in Wound Care, 3(5): 390-399. http://doi.org/10.1089/wound.2013.0520

18. Hyde, M., Wursten, B., Ballings, P., \& Palgrave, M. C. (2017). Flora of Zimbabwe: Species information: Costus afer. Retrieved from http://www.zimbabweflora.co.zw/speciesdata/species.php?species_id=116190

19. Ijioma, S. N., Nwosu, C. O., Emelike, C. U., Okafor, A. I., \& Nwankwo, A. A. (2014). Antinociceptive Property of Costus afer Ker Stem Juice and Ethanol Leaf Extract in Albino Rats. Comprehensive Journal of Medical Sciences, 2(2): 14-19.

20. Kitch, S. (2014). Copper Accelerates Skin Healing. Retrieved May 30, 2017, from http://www.copperme.com/copper-accelerates-skin-healing/

21. Kitchener, R. L., \& Grunden, A. M. (2012). Prolidase function in proline metabolism and its medical and biotechnological applications. Journal of Applied Microbiology, 113(2): 233-247. http://doi.org/10.1111/j.1365-2672.2012.05310.x

22. Kokane, D. D., More, R. Y., Kale, M. B., Nehete, M. N., Mehendale, P. C., \& Gadgoli, C. H. (2009). Evaluation of wound healing activity of root of Mimosa pudica. Journal Of Ethnopharmacology, 124: 311-315. http://doi.org/10.1016/j.jep.2009.04.038

23. Mahibalan, S., Stephen, M., Nethran, R. T., Khan, R., \& Begum, S. (2016). Dermal wound healing potency of single alkaloid (betaine) versus standardized crude alkaloid enriched-ointment of Evolvulus alsinoides. Pharmaceutical Biology, 54(12): 2851-2856. http://doi.org/10.1080/13880209.2016.1185636

24. Masson, P. (1929). Some histological methods. Trichrome stainings and their preliminary technique. Bulletin of the International Association of Medicine.

25. Mendonca, R. J. de, \& Coutinho-Netto, J. (2009). Cellular aspects of wound healing. Anais Brasileiros de Dermatologia, 84(3): 1-6. http://doi.org/http://dx.doi.org/10.1590/S0365-05962009000300007

26. Nesterova, Y. V., Povetieva, T. N., Suslov, N. I., Zhdanov, V. V., Hrichkova, T. Y., Udut, E. V., ... Dygai, A. M. (2012). Regeneratory characteristics of complex extract and isolated diterpene alkaloids of Aconitum baikalense. Bulletin of Experimental Biology and Medicine, 152(4): 439-443.

27. Ngameni, B., Fotso, G. W., Kamga, J., Ambassa, P., Abdou, T., Fankam, A. G., ... Abegaz, B. M. (2013). 9 Flavonoids and Related Compounds from the Medicinal Plants of Africa. In Medicinal Plant Research in Africa (pp. 301-350). http://doi.org/10.1016/B978-0-12-405927-6.00009-6

28. NIH. (2016). Magnesium - Health Professional Fact Sheet. Retrieved May 30, 2017, from https://ods.od.nih.gov/factsheets/Magnesium-HealthProfessional/

29. Odugbemi, T. (2008). A Textbook of Medicinal Plants from Nigeria. Lagos, Nigeria: University of Lagos Press.

30. Omokhua, G. E. (2011). Medicinal and Socio-Cultural Importance of Costus Afer (Ker Grawl) in Nigeria. African Research Review, 5(5): 282-287. http://doi.org/http://dx.doi.org/10.4314/afrrev.v5i5.22

31. Rude, R. K. (2012). Magnesium. In A. C. Ross, B. Caballero, R. J. Cousins, K. L. Tucker, \& T. R. Ziegler (Eds.), Modern Nutrition in Health and Disease (11th ed., pp. 159-174). Baltimore: Lippincott Williams \& Wilkins.

32. Saini, S., Dhiman, A., \& Sanju, N. (2016). Traditional Indian Medicinal Plants with Potential Wound Healing Activity: A Review. International Journal of Pharmaceutical Sciences and Research, 7(5): 1809-1819.

33. Sen, C. K., Khanna, S., Venojarvi, M., Trikha, P., Ellison, E. C., Hunt, T. K., \& Roy, S. (2002). Copper-induced vascular endothelial growth factor expression and wound healing. American Journal of Physiology - Heart and Circulatory Physiology, 282(5): H1821-H1827. http://doi.org/10.1152/ajpheart.01015.2001

34. Sotocina, S. G., Sorge, R. E., Zaloum, A., Tuttle, A. H., Martin, L. J., Wieskopf, J. S., ... Mogil, J. S. (2011). The Rat Grimace Scale: A Partially Automated Method for Quantifying Pain in the Laboratory Rat via Facial Expressions. Molecular Pain, 7(55): 1744-8069. http://doi.org/10.1186/1744-8069-7-55

35. Thakur, R., Jain, N., Pathak, R., \& Sandhu, S. S. (2011). Practices in wound healing studies of plants. EvidenceBased Complementary and Alternative Medicine, 2011: 438056. http://doi.org/10.1155/2011/438056

36. Tonkiri, A., Essien, E. B., Akaninwor, J. O., \& Ogbomade, R. S. (2015). Protective Effect of Costus afer on Lipid Profile and Hepatic Damage in Ethanol - Induced Liver Cirrhosis in Rats, 6(2): 53-61. http://doi.org/10.9734/IJBcRR/2015/14577 
37. Tsala, D. E., Amadou, D., \& Habtemariam, S. (2013). Natural wound healing and bioactive natural products. Phytopharmacology, 4(3): 532-560.

38. Uchegbu, R. I., Akalazu, J. N., Ibe, C. O., Ahuchaogu, A. A., \& Amadikwa, C. U. (2016). Chemical Composition of the Stem Extract of Costus afer ( Bush Cane ) and Its Antimicrobial Activity. British Journal of Pharmaceutical Research, 10(5): 1-9. http://doi.org/10.9734/BJPR/2016/24770

39. Velnar, T., Bailey, T., \& Smrkolj, V. (2009). The wound healing process: an overview of the cellular and molecular mechanisms. The Journal of International Medical Research, 37(5): 1528-1542. http://doi.org/10.1177/147323000903700531

40. Vogel, A. I. (1989). Atomic Absorption and Flame Emission Spectroscopy. In G. H. Jeffery, J. Basseyy, J. Mendham, \& R. C. Denney (Eds.), Vogel's Textbook of Quantitative Chemical Analysis (5th Ed.). England: Longman Scientific and Technical. pp. 779-815

41. Wansi, J. D., Devkota, K. P., \& Tshikalange, E. (2013). 14 - Alkaloids from the Medicinal Plants of Africa. In Medicinal Plant Research in Africa (pp. 557-605). http://doi.org/10.1016/B978-0-12-405927-6.00014-X

42. Yannas, I. V. (2008). The relation between wound contraction, scar formation and regeneration. Scar J. 1: 1-15. 